\title{
CORK ASYLUM CHURCH
}

Early in March the new Church for the Protestant inmates of the Cork District (Eglinton) Asylum was opened by the Bishop. It is an exceedingly fine Gothic building, consisting of chancel, nave, vostry-room, porch, tower, and spire, with an excellent bell. The windows are filled with tinted glass and ruby borders, and the inside walls are lined with red brick and coloured bands, giving a warm and pleasing appearance to the interior of the building. The grounds around the Church are tastefully laid with trees, plants, and grass plots, all the work of the patients. Dr. Eames is to be congratulated on the success of this undertaking. The Bishop, in his sermon, said that while they could not tell all the causes that led to mental aberration, he felt satisfied that the medical gentlemen present, and especially Dr. Eames, would agree with him that in drink they would, at any rate, find one cause and trace one germ leading to insanity.

"A very splendid luncheon"-from which we doubt not the above-mentioned germ was carefully excluded-" was subsequently given by some of the governors to the Bishop and Clergy, and many other guests, in the great Hall of the Asylum, one of the largest in Ireland." The kindly Bishop, in responding to the toast of his health, said " he appreciated the good feeling of those persons who, although not able to attend the service in the Church, yet joined with them at the lnncheon." As we cannot suppose the speaker to have been ironical, the observation bespeaks a truly liberal mind.

\section{Obituary.}

PROFESSOR BERNHARD VON GUDDEN.

The melancholy catastrophe by which the life of this distinguished alienist came to a sudden and violent end, on the evening of Sunday, June 13, at the Starnberg Lake, Bavaria, is known throughont the civilized world. But commiseration for the fate of the mad monarch who occasioned it almost throws into the shade, in the public mind, that of the unfortunate physician, who, if he may seem to have displayed undue disregard of precautions, acted chivalrously in the belief that he should, by the course he pursued, cause the least irritation and pain to his royal patient, and concluded, not without some reason, that he would be sufficiently strong physically, and by his moral influence, to prevent any accident happening. Now that all is over, and Dr. von Gudden has fallen a victim to his well-intentioned proceeding, it is easy to criticise his action, and to accuse him of culpable rashness. But uppermost in the minds of mental physicians everywhere onght to be, and no doubt is, the loss sustained by Psychiatry, and pity for him and his family in the sad fate which has overtaken him. His narne must be added to the not inconsiderable list of physicians who have been either injnred in person and health, or killed outright by patients of whom they have had charge. The life of the mental physician is in trath con. stantly in danger. He carries it in his hand, and may at any moment have to resign a career of intelligent usefulness and devotion at the hands of some one deprived by disease of both intelligence and useful purpose.

Dr. von Gudden was, in the first instance, assistant physician at the Irrenan. 
stalt, at Illenan, made celebrated by Roller, and we were strack with his mental qualities more than thirty years ago when we formed his acquaintance during a visit of several days to that asylum. He was, at that time, deroting himself to pathological study, and laying the foundation of that extensive knowledge which subsequently made the Medical Director of the Kreisirrenanstalt at Munich so high an anthority in Mental Medicine and so justly honoured a Professor of Psychiatry in the University there-the "hochverehrte Lehrer" of many a German stadent past and present.

Last antamn Dr. von Gadden presided over the annual meeting of the German Psychological Association at Baden, and was President of the Section of Psychiatry at the meeting of German Physicians and Naturalists held immediately afterwards, at Strasbourg. Little did those think who had the pleasure of seeing his striking form and intellectual face on these occasions, and hearing his hearty genial welcome, that before another of these annual gatherings his voice would be abruptly silenced by so cruel a fate, and his eminent services to science terminated by a royal hand.

The funeral of Dr. v. Gudden took place on June 16, at the subarban cemetery, Mnnich, and was attended by Baron von Lutz, President of the Council, Baron von Crailsheim, Minister for Foreign Affairs, and Baron von Feilitzsch, Minister of the Interior. Several representatives of the civil authorities and many officers and military surgeons were also present, as well as delegates from the local medical societies, the students of Munich, and the whole of the Professors of the University. Wreaths were laid on the grave by Baron Wolfskehl on behalf of the Prince Regent, by the Dean as representing the University, and by Privy-Councillor Rothmund in the name of the medical faculty.

Of the suicide of King Ladwig of Bavaria and his extraordinary career we do not speak now, but intend to retarn to the subject in the next namber of the Journal.

\section{DR. BENJAMIN CONSTANT INGELS.}

\section{(Honorary Member of the British Medico-Psychological Association).}

We regret to record the unexpected death of the well-known Secretary of the Society of Mental Medicine, Belgium, the Physician-Superintendent of the Guislain Asylum, Ghent, and the editor of the "Leçons Urales sur les Phréno. pathies " of the renowned Belgian alienist, after whom this hospital was called, and to whom he succeeded. Those who in September last attended the Antwerp Congress of Psychiatry will not forget the urbanity and kindness of the Honorary Secretary to the Congress, combined with a modesty which made him always content to efface himself.

On April 26, Dr. Ingels made a post-mortem examination of one of the patients in the Hospice Guislain, who died of empyema. He grazed his hand with a rib in removing the langs. The wound was at once canterised, but in twenty-four hours ferer set in, the axillary glands became swollen and painful, and in the course of a fortnight a very large abscess formed. It was opened, but the pyrexia continued in spite of 90 grains of quinine, and he died a martyr to medical science, May 22, 1886, in his 56th year. The funeral was attended by a large concourse of people. " Oar Ingels," writes M. Jules Morel, "was known as the most sympathetic of men, and I may say I know no one who bore any antipathy to him." Before the cortège left the asylum six dis-

XXXII. 